\title{
Kajian Penanda Genetik Tarsius bancanus dan Tarsius spectrum dengan Sekuen D-Loop Parsial DNA Mitokondria
}

\section{Study on Genetic marker in Tarsius bancanus and Tarsius spectrum Using Mitochondrial DNA D-loop Partial Sequences}

\author{
Rini Widayanti ${ }^{1 *}$, Dedi Duryadi Solihin ${ }^{2}$ \\ ${ }^{1}$ Fakultas Kedokteran Hewan, Universitas Gadjah Mada, Yogyakarta \\ E-mail: riniwida@yahoo.co.uk *Penulis untuk korespondensi \\ ${ }^{2}$ Departemen Biologi, FMIPA, Institut Pertanian Bogor, Bogor
}

\begin{abstract}
The objective of this research was to study the specific genetic marker on $D$-loop region of Tarsius bancanus and Tarsius spectrum. The sequencing of PCR product using primer DLTARPROF on D-loop resulted in base sequence of $270 \mathrm{nts}$. Result of D-loop fragments sequencing was put on multiple alignment with other primates from Genbank with the aid of software Genetyc-Win Version 3.0 and Clustal W, and was analyzed using MEGA program version 3.1. The genetic distance was based on nucleotide $D$-loop, the smallest genetic distance was $0 \%$ and the biggest was $11.8 \%$ and the average was $2.3 \%$. The phylogenetic tree using neighbor Joining Method based on some nucleotide sequence on $D$-loop region could not be used to differentiate between Tarsius bancanus and Tarsius spectrum.
\end{abstract}

Key words: Tarsius, D-loop, sequencing, mt-DNA, genetic

Diterima: 21 Maret 2007, disetujui: 03 Agustus 2007

\section{Pendahuluan}

Tarsius merupakan primata endemik Indonesia yang keberadaannya semakin memprihatinkan. Di Indonesia, berdasar data morfologi yang didukung vokalisasi dikenal ada 7 spesies tarsius, yaitu T. bancanus (di Sumatra dan Kalimantan), T. spectrum, T. dianae, $T$. pumilus, $T$. sangiriensis dan $T$. pelengensis (di Sulawesi) (Musser \& Dagosto, 1987; Groves, 2001; Shekelle, 2003). Upaya pelestarian satwa ini telah dilakukan dengan adanya peraturan pemerintah mengenai larangan untuk berburu dan usaha konservasi baik secara in situ maupun ex situ. Informasi genetik pada tarsius sampai saat ini masih sangat kurang, sedangkan informasi ini sangat dibutuhkan untuk tujuan konservasi. Suatu kenyataan, bahwa tarsius banyak diperdagangkan secara illegal baik di dalam maupun ke luar negeri dan tidak sedikit tarsius hasil tangkapan ini yang gagal diperdagangkan pada saat pemeriksaan. Oleh karena satwa ini secara morfologis sulit dibedakan, maka upaya pengembalian tarsius ke habitatnya (hasil konservasi ex situ atau hasil penangkapan liar) merupakan problem tersendiri. Upaya untuk menanggulangi masalah tersebut maka perlu dilakukan penelitian untuk mendapatkan penanda genetik untuk masing-masing spesies tarsius (secara morfologi antara T. spectrum dan $T$. bancanus mempunyai perbedaan cukup jelas, terutama pada ekor dan bulu tubuh, kecuali antar spesies dari Sulawesi, sulit dibedakan oleh masyarakat awam).

D-loop merupakan lokasi non-coding pada mt-DNA yang mempunyai laju mutasi tinggi, sehingga sering digunakan untuk meneliti hubungan antarspesies dan intra spesies (terutama populasi). Menurut Sbisa et al., (1997) yang diacu dalam Randi dan Lucchini (1998), lokasi D-loop dibagi menjadi 
3 domain, domain 1 (berbatasan dengan tRNA $^{\text {Pro }}$ ) bersifat variatif, domain 2 (tengah) bersifat kekal dan domain 3 bersifat variatif. Tujuan penelitian ini adalah melihat adanya keragaman genetik pada daerah $D$-loop parsial dari T. bancanus dan T. spectrum.

\section{Metode Penelitian}

\section{Bahan DNA}

Dalam penelitian ini digunakan 2 contoh Tarsius spectrum asal Tangkoko, Batuangus, Sulawesi Utara, 2 contoh $T$. spectrum dari Air Madidi, Sulawesi Utara dan 8 contoh Tarsius bancanus asal Lampung, Sumatra Selatan.

Primer amplifikasi $D$-loop parsial yaitu DLTARPROF 5' CTGGCATTCTCCATAAACT 3' dan DLTARBFR 5' GTTGCTGATTTCACGGAG GAAG 3'.

\section{Ekstraksi DNA}

DNA total diekstraksi dari otot. Preparasi contoh otot mengikuti metode Duryadi (1993). Setiap otot (50-100mg) secara terpisah digerus dalam larutan STES $\{1 \%$ (W/V) SDS; $50 \mathrm{mM}$ Tris-HCl, pH 9,0; 0,1 M EDTA, pH 8,0; 0,2 M $\mathrm{NaCl}$. Selanjutnya ditambah dengan digestion buffer (larutan STES + 0,5 mg/ml Proteinase
K) sebanyak 500 ul, kemudian diinkubasi pada penangas air suhu $55^{\circ} \mathrm{C}$ selama \pm 16 jam atau semalam.

Purifikasi DNA Total mengikuti Sambrook et al., (1989) dimodifikasi Duryadi (1993), yaitu dengan penambahan Phenol: cloroform: Isoamil-Alkohol (25:24:1). DNA kemudian dipresipitasi dengan alkohol absolut dan dicuci menggunakan alkohol $70 \%$.

\section{Amplifikasi DNA dengan PCR}

Komposisi $50 \mu$ campuran pereaksi PCR terdiri dari 2,5 mM $\mathrm{MgCl}_{2}, 10 \mathrm{mM}$ dNTPs, 100-300 ng DNA cetakan, 20-100 pmol masing-masing primer dan $2 \mathrm{U}$ Taq polimerase (Bio lab) beserta bufernya. Amplifikasi DNA dengan PCR menggunakan mesin GeneAmp ${ }^{R}$ PCR system 2400 (Perkin Elmer), dengan kondisi sebagai berikut: denaturasi awal selama 2 menit pada suhu $94^{\circ} \mathrm{C}$ selanjutnya diikuti dengan $94^{\circ} \mathrm{C}$ selama 30 detik untuk denaturasi, $55^{\circ} \mathrm{C}$ selama 45 detik untuk penempelan primer (annealing), $72^{\circ} \mathrm{C}$ selama 1 menit untuk pemanjangan (elongation); amplifikasi dilakukan sebanyak 35 siklus kemudian diakhiri 5 menit pada $72^{\circ} \mathrm{C}$. Skema dari $D$-loop beserta bagiannya disajikan pada Gambar 1.

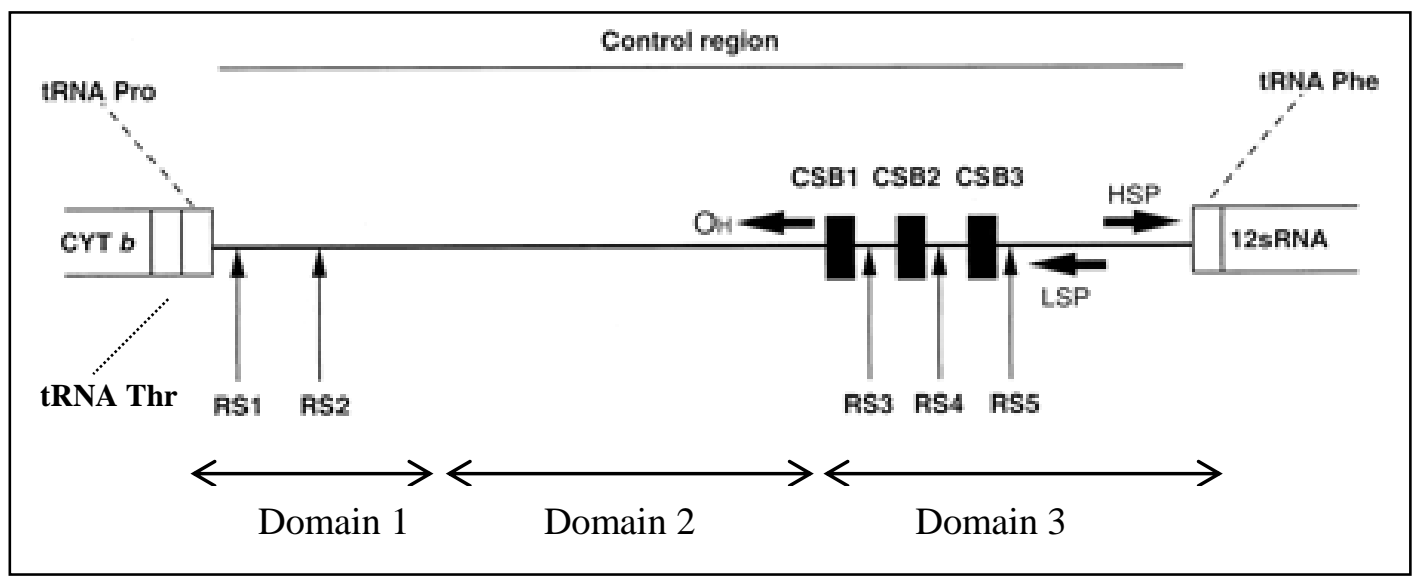

Gambar 1. Skema organisasi daerah kontrol mt-DNA (D-Loop) pada mamalia. CSB1, CSB2, CSB3:blok runutan pendek bersifat kekal; OH:titik awal replikasi untai H; HSP: promotor replikasi untai H; LSP: promotor transkripsi untai L; RS1-RS5: lokasi runutan kopi berulang pada spesies yang berbeda (Savolainen et al., 2000) 


\section{Penentuan sekuen nukleotida}

Produk PCR hasil amplifikasi dimurnikan menggunakan GFX Column purification kit (Amersham, USA). Reaksi untuk sekuensing D-loop parsial menggunakan larutan pereaksi Thermo Sequenase Cy5 Dye Terminator Cycle Sekuencing Kit (Amersham, USA) dengan mesin GeneAmp ${ }^{R} P C R$ system 2400 (Perkin Elmer). Kondisi untuk reaksi sekuensing adalah sebagai berikut: denaturasi awal selama 2 menit pada suhu $94^{\circ} \mathrm{C}$ selanjutnya diikuti dengan $94^{\circ} \mathrm{C}$ selama 30 detik, $55^{\circ} \mathrm{C}$ selama 45 detik, $72^{\circ} \mathrm{C}$ selama 1 menit; reaksi amplifikasi sebanyak 35 siklus kemudian diakhiri dengan penambahan (extension) selama 5 menit pada $72^{\circ} \mathrm{C}$. Sekuensing nukleotida menggunakan alat sequenser DNA otomatis ALFexpress II (Amersham pharmacia biotech), pada kondisi $1500 \mathrm{~V}$, arus listrik $60 \mathrm{~mA}$, daya $25 \mathrm{~W}$, suhu $55^{\circ} \mathrm{C}$, selama 700 menit.

\section{Analisis Data}

Penjajaran berganda homologi sekuen nukleotida $D$-loop dianalisis dengan bantuan perangkat lunak Genetyx-Win versi 3.0 dan Clustal W (Thompson et al., 1994).
Analisis filogeni menggunakan perangkat lunak MEGA versi 3.1 (Kumar et al., 2001) dengan metode bootstrapped Neighbor-Joining dengan 1000 kali pengulangan. Sebagai spesies pembanding digunakan $T$. bancanus (Nomor akses NC_002811), Nycticebus coucang (NC_002765), Lemur catta (NC_004025), Cebus albifrons (NC_002763), Lagothrix lagotricha (AF 213965), Macaca sylvanus (NC_002764), Pan paniscus (NC_001644), Gorilla gorilla (NC_001645), Homo sapiens (NC_001807).

\section{Hasil dan Pembahasan}

\section{Amplifikasi D-loop parsial}

Amplifikasi daerah D-loop parsial pada Tarsius sp. menggunakan pasangan primer DLTARPROF dan DLTARBFR menghasilkan fragmen DNA berukuran $417 \mathrm{pb}$. Profil DNA hasil amplifikasi primer tersebut disajikan pada Gambar 2. Fragmen DNA tersebut berdasarkan runutan genom mtDNA T. bancanus (Schmitz et al., 2002) terdiri dari $27 \mathrm{pb}$ fragmen gen tRNA $^{\text {Pro }}$ dan $390 \mathrm{pb}$ fragmen $D$-loop.

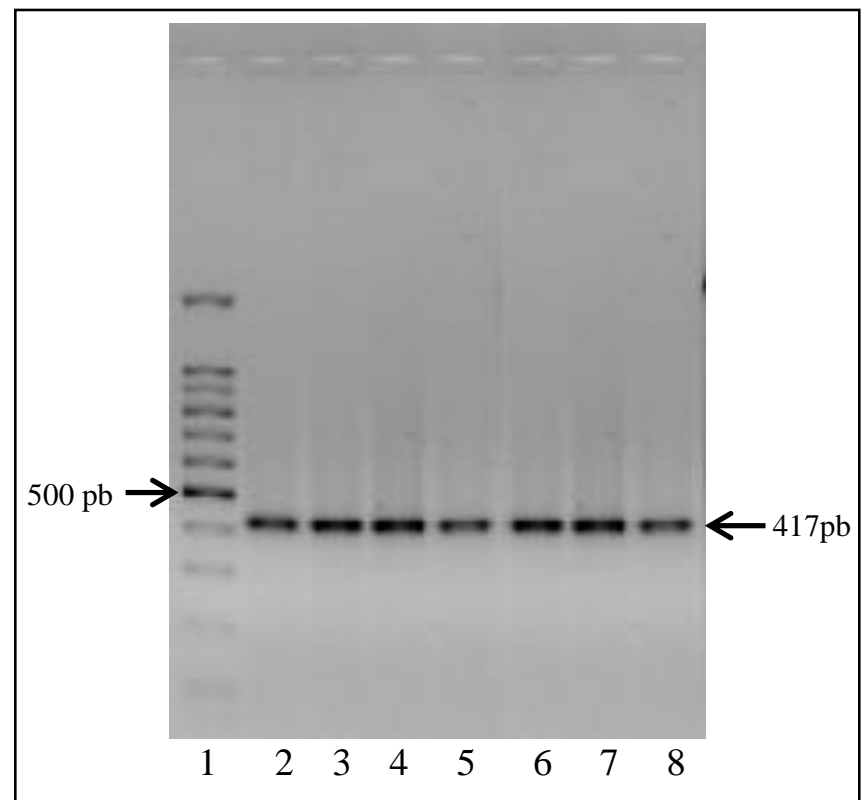

Gambar 2. Profil DNA Tarsius sp. hasil amplifikasi menggunakan pasangan primer DLTARPROFDLTARBFR. Keterangan: lajur 1. DNA penanda 100pb (Promega), lajur 2-8 DNA hasil amplifikasi menggunakan primer DLTARPROF- DLTARBFR 


\section{Penentuan sekuen nukleotida D-loop parsial}

Fragmen DNA D-loop parsial sepanjang 417 pb hasil amplifikasi primer DLTARPROF dan DLTARBFR setelah dilakukan sekuensing DNA menggunakan primer DLTARPROF dan disejajarkan dengan runutan genom $T$. bancanus dari Genbank diperoleh 270 sekuen nukleotida yang dapat dianalisis. Bagian yang tidak terbaca adalah sebanyak 147 basa, yaitu terletak pada ujung 5' primer DLTARPROF (Gambar 3).

Nukleotida beragam beserta situsnya dari Tarsius sp. disajikan pada Tabel 1. Data lengkap sekuen $270 \mathrm{nt}$ daerah D-loop parsial dapat dilihat dalam Widayanti (2006). Hasil perbandingan ke 270 nukleotida terhadap nukleotida $T$. bancanus asal Malaysia (Genbank) ditemukan sebanyak 31 nukleotida dikategorikan sebagai situs beragam. Akan tetapi dari hasil penelitian yang dibandingkan terdapat 6 situs nukleotida beragam. Rata-rata rasio transisi terhadap transversi adalah 3,128.
Jarak genetik yang dihitung menggunakan model 2 parameter Kimura ditemukan nilai paling kecil adalah $0 \%$, nilai paling besar $11,8 \%$ dengan rata-rata 2,3\%. Adanya situs beragam yang sangat kecil antara $T$. bancanus dan $T$. spectrum hasil penelitian serta tidak adanya perbedaan dari ke $4 T$. spectrum yang berasal dari Tangkoko dan Air Madidi (0\%) dan juga terhadap T. bancanus 1, 2, 4, dan 6 (0\%), hal ini menunjukkan bahwa daerah $D$ loop merupakan daerah yang memiliki tingkat kemiripan yang sangat tinggi. Di dalam populasi $T$. bancanus pada penelitian ini ada perbedaan namun sangat kecil sekali. Tingkat kemiripan yang sangat tinggi ini sama seperti penelitian yang dilakukan Shimada (2004), bahwa pada daerah D-loop domain I (605 nt) dari simpanse di Afrika tidak dapat untuk membedakan spesies simpanse yang hidup di daerah gunung Nimba dan Bossou, Afrika Barat.

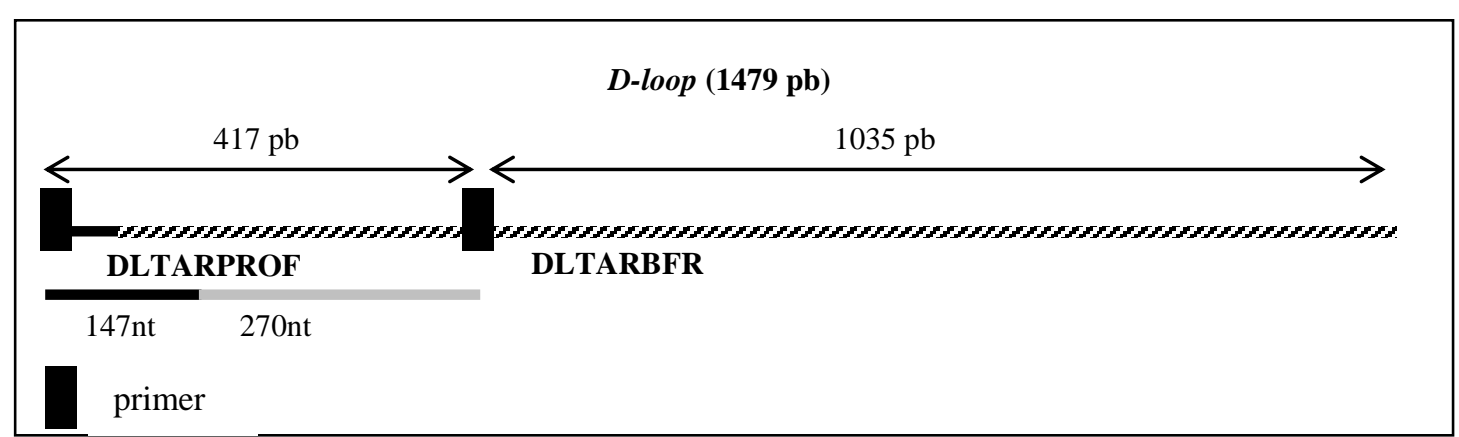

Gambar 3. Skema daerah D-loop dan sebagian daerah hasil sekuensing DNA (Berukuran $270 \mathrm{nt}$ ) yang dipakai untuk analisis keragaman genetik pada Tarsius sp.

Tabel 1. Nukleotida beragam pada daerah D-loop parsial T. bancanus, $T$. spectrum hasil penelitian dan $T$. bancanus asal Malaysia (Genbank)

\begin{tabular}{|c|c|}
\hline & 31 situs nukleotida beragam (dari 270 ) \\
\hline T_banc1 & ССССTTCTAATTCGGTCAACTATCGTTTCCT \\
\hline T_banc2 & $\ldots \ldots \ldots \ldots \ldots \ldots \ldots$ \\
\hline T_banc3 & 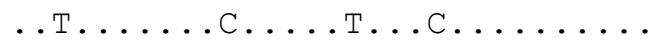 \\
\hline T_banc4 & 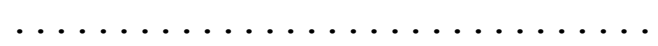 \\
\hline T_banc5 & $\ldots \ldots$. . . . . . .А. \\
\hline T_banc6 & $\ldots$. $\ldots \ldots \ldots \ldots \ldots \ldots \ldots$ \\
\hline T_banc7 & 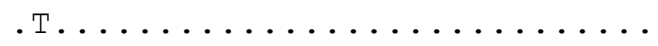 \\
\hline T_banc8 & 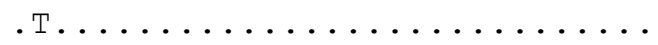 \\
\hline T_spec1 & 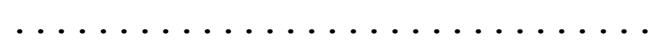 \\
\hline T_spec2 & 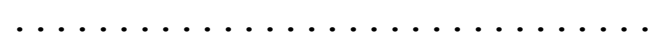 \\
\hline T_spec3 & 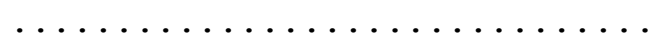 \\
\hline T_spec4 & 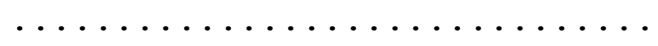 \\
\hline T_banc* & T.TTCCTCGCCCAACAAGGT.GCTACCCT.A \\
\hline
\end{tabular}


Hasil penelitian ini sangat berbeda dengan sifat $D$-loop yang memiliki laju mutasi tinggi, yang dapat digunakan untuk membedakan pada tingkat populasi, terutama pada domain I dan III. Fragmen D-loop hasil penelitian $(270 \mathrm{nt})$ menurut skema organisasi daerah D-loop (Savolainen et al., 2000) terletak pada domain 1, tetapi fragmen DNA tersebut sangat kekal pada $T$. bancanus (Sumatra) dan $T$. spectrum. Keadaan ini sangat berbeda dengan pendapat Sbisa et al., (1997), bahwa daerah D-loop dibagi menjadi 3 domain, domain 1 (berbatasan dengan $\mathrm{tRNA}^{\text {Pro }}$ ) bersifat variatif, domain 2 (tengah) bersifat kekal dan domain 3 bersifat variatif. Menurut Hoelzel et al., (1994), di daerah $D$-loop ditemukan 5 posisi susunan urutan berulang (repetitive sequence, $R S$ ) 1 sampai dengan 5 , RS1, dan RS2 berada pada ujung 5' D-loop sedangkan RS3, RS4, dan RS5 berada pada ujung 3' dari D-loop. Menurut Schmitz et al., (2002), pada T. bancanus ditemukan runutan berulang pada posisi RS3 sebanyak $22 \mathrm{pb}$ dengan pengulangan bervariasi dari 4 - 15, sedangkan menurut Fumagalli et al., (1996); Wilkinson dan Chapman(1991) ukuran panjang nukleotida $D$ loop bervariasi karena duplikasi atau delesi dari urutan berulang. Jadi, kemungkinan daerah yang memiliki nukleotida bervariasi pada tarsius terletak di posisi RS3 yang terletak pada domain 3.

Adanya perbedaan yang cukup besar antara $T$. bancanus dan T. spectrum (hasil penelitian) terhadap $T$. bancanus pembanding, hal ini kemungkinan karena perbedaan letak geografis, iklim, asal usul, dan lamanya waktu pemisahan. Menurut Darlington (1966), tarsius di Sulawesi merupakan salah satu mamalia Kalimantan yang distribusinya sampai ke pulau Sulawesi. Untuk mendapatkan gambaran hasil yang lebih baik seharusnya juga dibandingkan dengan sekuen DNA T. bancanus asal Kalimantan. Namun, karena keterbatasan dalam memperoleh sampel maka pada penelitian ini tidak ada pembanding tarsius asal Kalimantan.

\section{Hubungan kekerabatan Tarsius sp. berdasar sekuen nukleotida $D$-loop parsial}

Analisis hubungan kekerabatan antar contoh tarsius dilakukan terhadap 270 nukleotida yang menyusun D-loop parsial dengan spesies primata lain yang diambil dari Genbank dipakai sebagai pembanding. Gambar 4 menyajikan filogram berdasar sekuen nukleotida daerah D-loop parsial. Pada penelitian ini hanya dilakukan penjajaran nukleotida $D$-loop parsial sebesar $270 \mathrm{nt}$ karena keterbatasan data sekuen nukleotida $T$. spectrum. Apabila dilakukan penjajaran nukleotida di bagian lain $D$-loop tidak menutup kemungkinan menyebabkan pergeseran pola filogram tarsius.

Hasil analisis filogenetik menggunakan metode NJ ini menempatkan kedua spesies tarsius hasil penelitian berada terpisah dengan T. bancanus pembanding dan pengelompokan ini didukung oleh nilai bootstrap 100\%. Sedangkan $T$. bancanus (Sumatera) dan $T$. spectrum berada dalam satu kelompok dan pengelompokan ini didukung oleh nilai bootstrap $100 \%$. Hasil ini juga didukung oleh jarak genetik yang sangat kecil $(0,5 \%)$ antara T. spectrum dan T. bancanus (Sumatera). Hal ini menunjukkan bahwa daerah $D$-loop mempunyai homologi yang sangat tinggi pada $T$. bancanus dan $T$. spectrum. Hal ini sama seperti penelitian yang dilakukan Shimada (2004), bahwa pada daerah D-loop region I (605 nt) simpanse di Afrika tidak dapat untuk membedakan spesies simpanse tersebut.

Menurut Napier dan Napier (1983), berdasar morfologi, tarsius masih menjadi perdebatan apakah masuk subordo Prosimian (kelompok primata kecil) atau intermedier (di pertengahan) antara subordo Anthropoidea (kelompok primata besar) dan Prosimian. Sedangkan menurut Groves (2001), primata dibagi menjadi subordo Strepsirrhini (sebelumnya Prosimian) dan subordo Haplorrhini (sebelumnya Anthropoidea), tarsius masuk ke dalam subordo Haplorrhini. Hasil analisis filogenetik ke 270 nukleotida daerah $D$-loop parsial pada penelitian ini mengelompokkan Tarsius sp. masuk ke dalam sub ordo Haplorrhini (anthropoidea), seperti pengelompokan Tarsius sp. yang dilakukan oleh Groves (2001) yaitu berdasar data morfologi dan Ross et al., (1998) berdasar data 291 karakter morfologi. 


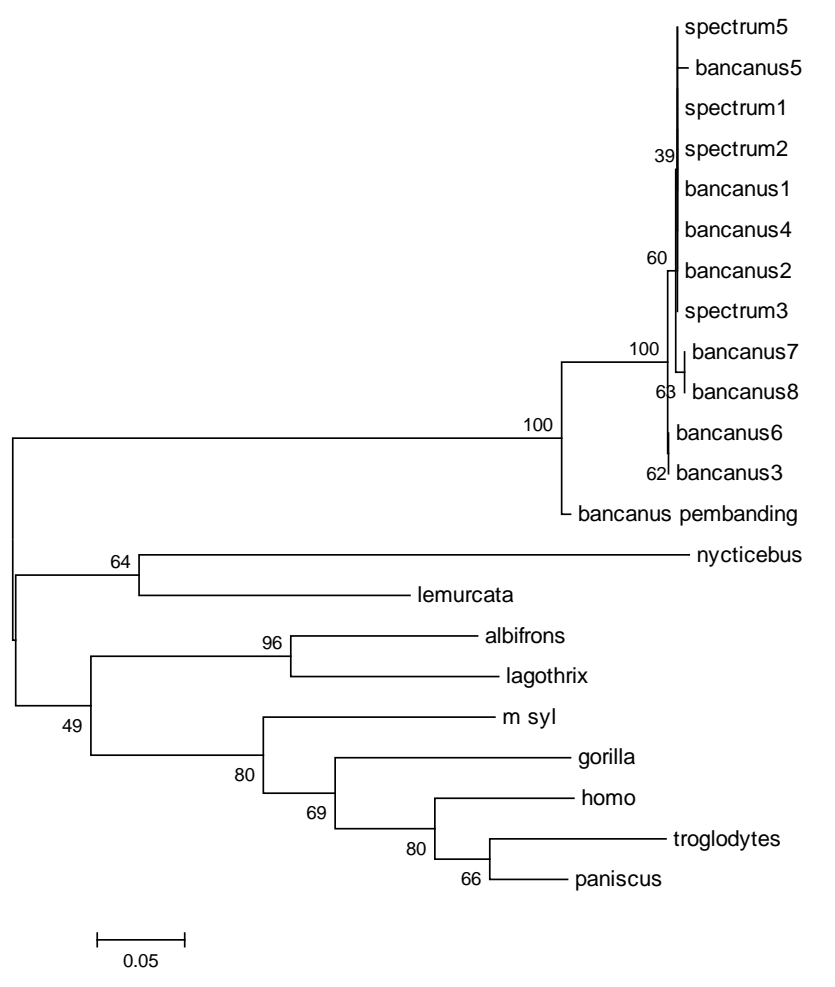

Gambar 4. Filogram menggunakan metode Neighbor joining dari nukleotida lokasi $D$-loop parsial (berukuran $270 \mathrm{nt}$ ) Tarsius sp. dengan spesies primata lain

\section{Kesimpulan dan Saran}

\section{Kesimpulan}

Sekuen nukleotida DNA pada daerah $D$ loop parsial tidak dapat digunakan untuk membedakan interspesies, antara T. bancanus dan $T$. spectrum. Namun demikian sekuen nukleotida $D$-loop dapat digunakan untuk mengelompokkan tarsius ke dalam kelompok Haplorrhini.

\section{Saran}

Perlu penelitian lebih lanjut pada lokasi D-loop region III untuk lebih memantapkan hubungan kekerabatan antar tarsius.

\section{Ucapan Terima Kasih}

Terima kasih disampaikan kepada Dr. Saroyo, Dr. Drs. Yulius Duma, Msi dan Dr. Hengki Johannis Kiroh yang telah membantu dalam memperoleh sampel tarsius.

\section{Daftar Pustaka}

Darlington, P.J. 1966. Zoogeography: The geographical distribution of animals. John Wiley. New York. 488-490.

Duryadi, D. 1993. Role possible du comportement dans I'evolution de Deux Souris Mus macedonicus et Mus spicilequs en Europe Centrale. Thesis Doctorat. France: Montpellier, Univ. Montpellier II, Sciences et Techniques du Languedoc.

Fumagalli, L., Taberlet, P., Favre, L. and Hausser, J. 1996. Origin and evolution of homologus repeated sequences in the mitochondrial DNA control region of shrews. Mol. Biol. Evol. 13: 31-46.

Groves, C. 2001. Primate Taxonomy. Smithsonian Inst Pr. London.

Hoelzel, A.R., Lopez, J.V., Dover, G.A. and O' Brien, S.J. 1994. Rapid evolution of a heteroplasmic repetitive in the mitochondrial DNA control region of carnivores. J. Mol. Evol. 39: 191199. 
Kumar, S., Tamura, K., Jakobsen, I.B. and Nei, M. 2001. Molecular evolutionary genetics analysis version 2.0. Pennsylvania State Univ. Inst of Molecular Evolutionary genetics.

Musser, G.G. and Dagosto, M. 1987. The identity of Tarsius pumilus, a pygmy species endemic to the montane mossy of Central Sulawesi. Am Museum Novitates 2867: 1-53.

Napier, J.R. and Napier, P.H. 1983. The natural history of the primates. British Museum (Natural History). Cromwell Road. London.

Randi, E. and Lucchini, V. 1998. Organization and evolution of mitochondrial DNA control region in the avian genus Alectoris. J. Mol. Evol. 47: 449-462.

Ross, C., Williams, B. and Kay, R.F. 1998. Phylogenetic analysis of anthropoid relationships. $J$. Human Evol. 35: 221-306.

Sambrook, J., Fritsch, E.F. and Maniatis, T. 1989. Molecular cloning. A Laboratory manual. Cold Spring Harbour Laboratory Pr. New York.

Savolainen, P., Arvestad, L. and Lunderberg, J. 2000. mtDNA tandem repeats in domestic dogs and wolves: Mutation mechanism studied by analysis of the sequence of imperfect repeats. J. Mol. Evol. 12: 474-488.

Sbisa, E., Tanzariello, F., Reyes, A., Pesole, G. and Saccone, C. 1997. Mammalian mitochondrial D-loop region structural analysis: identification of new conserved sequences and their functional and evolutionary implications. Gene 205: 125-140.
Schmitz, J., Ohme, M. and Zischler, H. 2002. The complete mitochondrial sequence of Tarsius bancanus: evidence for an extensive nucleotide compositional plasticity of primate mitochondrial DNA. Mol. Biol. Evol. 19: $544-553$

Shekelle, M. 2003. Taxonomy and Biogeography of Eastern Tarsiers. Doctoral thesis. St. Louis: Washington Univ.

Shimada, M.K. 2004. Mitochondrial DNA genealogy of chimpanzees in the Nimba mountains and Bossou, West Africa. Am. J. Primatol 64: 261-275.

Thompson, J.D., Higgins, D.G. and Gibson, T.J. 1994. CLUSTAL W: Improving the sensitivity of progressive multiple sequence alignment through sequence weighting, Positionspecific gap penalties and weight matrix choice. Nucleic Acid Res. 22: 4673-4680.

Wilkinson, G.S. and Chapman, A.M. 1991. Length and sequence variation in evening bat D-loop mtDNA. Genetics 128: 607-617.

Widayanti, R. 2006. Kajian penanda genetik gen cytochrome b dan daerah D-loop pada Tarsius sp. Disertasi. Bogor: Program Studi Primatologi, Institut Pertanian Bogor, Bogor. 